\title{
Pelayanan Penerbitan Buku Pelaut Berbasis Online
}

\author{
Harianty Anwar, Risma Niswaty, Sirajuddin Saleh \\ Universitas Negeri Makassar
}

\begin{abstract}
ABSTRAK
Penelitian ini bertujuan untuk mengetahui gambaran Pelayanan Penerbitan Buku Pelaut Berbasis Online Pada Kantor Kesyahbandaran Utama Makassar. Untuk mencapai tujuan tersebut peneliti menggunakan teknik pengumpulan data melalui, dokumentasi, observasi, dan wawancara dengan jumlah informan sebanyak 8. Data yang diperoleh dari hasil penelitian diolah dengan menggunakan analisis kualitatif untuk mengetahui Gambaran Pelayanan Penerbitan Buku Pelaut Berbasis Online Pada Kantor Kesyahbandaran Utama Makassar. Mengingat pelayanan tersebut telah menggunakan pelayanan berbasis online dan sistem pelayanan satu atap sehingga dapat dilihat dari beberapa indikator yaitu: (1) identifikasi Persyaratan, (2) Indentifikasi Prosedur, (3) Identifikasi Waktu, (4) Identifikasi Biaya/Tarif, (5) Identifikasi Produk Pelayanan, (6) Penanganan Pengadaan Pengaduan. Adapun kekurangan dari pelayanan penerbitan buku pelaut berbasis online terdapat di beberapa indikator yang perlu ditingkatkan seperti identifikasi waktu dan penanganan pengadaan pengaduan.
\end{abstract}

Kata kunci: Pelayanan, berbasis online

\section{ABSTRACT}

This study aims to determine the description of Publishing Services Books Online Based Sailors At the Office Kesyahbandaran Utama Makassar. To achieve that goal, the researcher used data collection technique through, documentation, observation, and interview with the number of informants as much as 8. The data obtained from the research result is processed by using qualitative analysis to know the description of the online book publishing service of the Seafarer Online at Kesyahbandaran Utama Makassar Office. Given that the service has used online-based services and a one-stop service system that can be viewed from several indicators: (1) identification of Requirements, (2) Identification of Procedures, (3) Identification of Time, (4) Cost / Tariff Identification, (5) Identification of Service Products, (6) Handling of Complaint Procurement. The lack of online booklets for online sailing services is available in several indicators that need to be improved, such as time identification and procurement handling.

Keyword: Service, online base

\section{PENDAHULUAN}

Zaman dahulu pelayanan tentu tidak terpisahkan dengan sebuah sitem atau sebuah prosedur (Al Fatta, 2007; Effendi \& Purnama, 2011; Gaol, 2008; Patria \& Yulianto, 2011; Rofi'ah, 2013). Walaupun minim akan perlengkapan yang canggih dan minimnya teknologi namun tetap pelayanan bagaikan sebuah keterikatan abadi dengan sebuah prosedur dan semakin berkembangnya zaman dan berubahnya waktu, sebuah pelayanan dan sistem akan berevolusi dengan beberapa hal yang menunjang dengan bantuan teknologi yang semakin maju. Salah 
satunya ialah sistem pelayanan administrasi dari sistem manual menuju sistem pelayanan berbasis online (Effendi \& Purnama, 2011; Nasikin, 2011; Putro \& Riasti, 2012).

Penyelenggaraan pelayanan publik merupakan upaya Negara untuk memenuhi kebutuhan dasar dan hak-hak sipil setiap warga Negara atas barang, jasa, dan pelayanan administrasi yang disediakan oleh penyelenggara pelayanan publik (Lembaga Administrasi Negara, 2003). Undang-Undang Dasar 1945 mengamanatkan kepada Negara untuk memenuhi kebutuhan dasar setiap warga Negara demi kesejahteraannya, sehingga efektivitas suatu sistem pemerintahan sangat ditentukan oleh baik buruknya penyelenggaraan pelayanan publik. Pembukaan UndangUndang Dasar 1945 pun secara tegas menyatakan bahwa salah satu tujuan didirikan Negara Republik Indonesia adalah untuk memajukan kesejahteraan publik dan mencerdaskan kehidupan bangsa. Selain itu, Pelayanan yang terbaik sebagaimana diuraikan pada pasal 7 dalam Undang-Undang Republik Indonesia Nomor 25 tahun 2009 tentang Pelayanan Publik.

Kantor Kesyahbandaran Utama Makassar adalah Unit Pelaksana Teknis yang berada di bawah naungan Kementrian Perhubungan dan bertanggung jawab kepada Menteri Perhubungan melalui Direktur Jenderal Perhubungan Laut di pelabuhan yang melaksanakan fungsi keselamatan dan ketertiban pelayaran serta pengawasan dan penegakan hukum di bidang pelayaran (Novistia, 2016). Syahbandar memiliki kewenangan tertinggi dalam melaksanakan koordinasi kegiatan keimigrasian, kekarantinaan dan kegiatan institusi pemerintah lainnya di pelabuhan. Kantor Kesyahbandaran Utama Makassar mempunyai tugas mengkoordinasikan dan melaksanakan keselamatan dan keamanan pelayaran. Dalam melaksanakan tugas sebagaimana dimaksud tersebut, kantor syahbandar menyelenggarakan fungsi: 1) Pelaksanaan pemeriksaan, pengujian dan sertifikasi kelaiklautan kapal sesuai dengan kewenangannya; 2) Pengawasan bongkar muat barang berbahaya, limbah bahan berbahaya dan beracun dan pengisian bahan bakar; 3) Pengawasan laik layar dan kepelautan, alih muat di perairan pelabuhan, keselamatan pengerukan, reklamasi dan pembangunan fasilitas pelabuhan sesuai dengan kewenangannya serta penerbitan Surat Persetujuan Berlayar; 4) Koordinasi dan pelaksanaan penanggulangan perlindungan lingkungan maritim; 5) Pelaksanaan bantuan pencarian dan penyelamatan (search and Rescue SAR), di Daerah Lingkungan Kerja (DLKr) dan Daerah Lingkungan Kepentingan (DLKp) pelabuhan; 6) Pelaksanaan ketertiban dan patroli, penyidikan tindak pidana pelayaran di dalam Daerah Lingkungan Kerja (DLKr) dan Daerah Lingkungan Kepentingan (DLKp) pelabuhan, serta Pengawasan Pekerjaan Bawah Air (PBA), salvage, penundaan dan pemanduan kapal; dan 7) Pengelolaan urusan tata usaha, kepegawaian, keuangan, hukum, dan hubungan masyarakat.

Berdasarkan observasi awal yang dilakukan pada tanggal 1 September 2016 sebelum memulai wawancara dengan pengguna jasa dalam hal Pelayanan Penerbitan Buku Pelaut Berbasis Online, kondisi di Kantor Kesyahbandaran Utama Makassar dalam hal pelayanan menunjukkan hasil yang kurang optimal. Penerapan sistem pelayanan secara online masih ditemukan hambatan bagi pengguna jasa seperti kesulitan mengakses situs pelayanan buku pelaut dan kurangnya sosialisasi dari pihak Syahbandar dalam hal pelayanan penerbitan buku pelaut berbasis online sehingga hanya kalangan tertentu saja yang mampu menjangkau sistem online tersebut seperti pengguna jasa yang memiliki usia produktif seperti mahasiswa pelayaran. Selain itu, tata ruang kantor pelayanan yang terpisah (tidak bersifat satu atap). 
Harianty Anwar, dkk, Pelayanan Penerbitan Buku Pelaut Berbasis Online |13

\section{METODE PENELITIAN}

Jenis penelitian yang digunakan adalah penelitian deskriptif kualitatif. Penelitian ini berfokus pada pelayanan penerbitan buku pelaut berbasis online pada kantor Kesyahbandaran Utama Makassar. Informan penelitian ini adalah orang yang dapat memberikan informasi atau keterangan yang berhubungan langsung dengan sistem pelayanan administrasi berbasis online pada Seksi Kepelautan Kantor Kesyahbandaran Utama Makassar yaitu pimpinan unit kerja, pengguna jasa, dan pegawai unit kerja. teknik pengumpulan data yang digunakan untuk mengumpulkan data dan informasi adalah observasi, wawancara, dan dokumentasi. Tehnik uji keabsahan data menggunakan uji kredibilitas. Tehnik analisis data yang digunakan dalam penelitian ini adalah menurut (Miles, Huberman, \& Saldana, 2014) yaitu pengumpulan data, reduksi data, penyajian data, dan penarikan kesimpulan.

\section{HASIL PENELITIAN PEMBAHASAN}

\section{Hasil Penelitian}

Penyajian data penelitian ini adalah data yang diperoleh dari pengumpulan data melalui observasi dan wawancara mendalam serta kelengkapan dokumen lain yang berkaitan dengan penelitian ini. Data yang disajikan erat kaitannya dengan fokus yang diteliti yaitu mengenai Pelayanan Penerbitan Buku Pelaut Berbasis Online pada Kantor Kesyahbandaran Utama Makassar. Penyajian data wawancara yang diperoleh terkait Pelayanan Penerbitan Buku Pelaut Berbasis Online pada Kantor Kesyahbandaran Utama Makassar berdasarkan beberapa fokus kemudian direduksi berdasakan data yang diperoleh. Wawancara dilakukan kepada Kepala Seksi Kepelautan Kantor Kesyahbandaran Utama Makassar, Staf Seksi Kepelautan Kantor Kesyahbandaran Utama Makassar, dan pengguna jasa. Dalam mengukur pelayanan pada penelitian ini berdasarkan pada penyusunan rancangan standar pelayanan yang memiliki fokus yaitu prosedur pelayanan, waktu penyelesaian, biaya pelayanan, produk pelayanan, sarana dan prasarana, dan kompetensi petugas pemberi pelayanan. Berikut hasil penelitian yang diperoleh:

\section{Prosedur Pelayanan}

Prosedur pelayanan yaitu dalam hal ini harus ditetapkan standar prosedur pelayanan yang dibakukan bagi pemberi dan penerima pelayanan termasuk prosedur pengaduan. Disamping itu, penyelenggara pelayanan wajib memiliki Standar Operasional Prosedur (SOP). Hasil yang diharapkan dari tahapan ini adalah tahapan proses pelayanan sebagai bahan peninjauan Standar Operasional Prosedur.

Kantor Kesyahbandaran Utama Makassar sebagai salah satu penyedia jasa pelayanan penerbitan buku pelaut berbasis online tentu memilki SOP sebagai uraian atau rangkaian tahapan yang harus dipenuhi pengguna jasa untuk memperoleh buku pelaut berbasis online. Untuk memperoleh buku pelaut, pengguna jasa harus memenuhi prosedur yang ditetapkan oleh pihak Syahbandar yaitu (1) Pengguna jasa mesuk ke situs www.dephub.go.id lalu pilih menu permohonan yang diinginkan (Buku baru/perpanjang/penggantian dll); (2) Lalu pengguna jasa 
mengisi formulir yang telah disediakan oleh aplikasi buku pelaut online; (3) Pilih lokasi Syahbandar terdekat untuk mencetak buku pelaut; (4) Print bukti pembayaran; (5) Selanjutnya pengguna jasa datang ke Syahbandar dan berikan bukti pendaftaran online beserta persyaratan; (6) Petugas Syahbandar memverifikasi dokumen permohonan pengguna jasa; (7) Verifikasi OK; (8) Pengguna jasa selanjutnya mengambil foto buku pelaut; (9) Pejabat Syahbandar menyetujui permohonan buku pelaut; (10) setelah itu, pengguna jasa dapat mencek email untuk selanjutnya memperoleh info tagihan PNBP (Penerima Negara Bukan Pajak) yang harus dibayar; (11) Apabila pengguna jasa telah memperoleh email tagihan pembayaran, selanjutnya pengguna jasa diminta membayar PNBP sesuai kode billing ke bank yang ditunjuk; (12) Selanjutnya pengguna jasa menyerahkan bukti pembayaran PNBP ke petugas Syahbandar; (13) Petugas lalu mencetak buku pelaut; (14) Pejabat yang berwenang selanjutnya mengesahkan buku pelaut; (15) Setelah semua prosedur telah dipenuhi, pengguna jasa berhak memperoleh buku pelaut. Hal tersebut diperkuat dengan SOP penerbitan buku perlaut pada halaman lampiran gambar 8 .

Berdasarkan keterangan Saharuddin, ST Kepala Seksi Kepelautan Kantor Kesyahbandaran Utama Makassar (wawancara, 22 Maret 2017) menjelaskan bahwa:

Tentunya ada SOP dan sudah sesuai dengan SOP. Standar tersebut dari Direktorat Jenderal Perhubungan Laut, Kantor Kesyahbandar Utama Makassar hanya sebatas operator sehingga petugas pelayanan hanya mengapload dan yang menyetujui data pendaftaran online itu dilaksanakan oleh Direktorat Jenderal Perhubungan laut. Dengan demikian data yang telah pengguna jasa daftarkan secara online terintegrasi dengan data yang berhubungan dengan persyaratan teknis maupun persyaratan administrasi.

Berdasarkan paparan yang dikemukakan oleh Kepala Seksi Kepelautan Kantor Kesyahbandaran Utama Makassar, segala prosedur yang berlaku di Syahbandar mengenai alur prosedur buku pelaut online telah sesuai dengan Standar Operasional Prosedur yang berlaku dan dilaksanakan oleh Direktorat Jenderal Perhubungan laut. Sehingga tidak ada alasan untuk tidak menerapkan sistem online dalam hal pelayanan penerbitan buku pelaut.

Selanjutnya, adapun keterangan Staff Seksi Kepelautan Kantor Kesyahbandaran Makassar Yuyun Sri Wahyuni, ST (wawancara, 20 Maret 2017) :

Mengenai sosialisasi SOP tentang buku pelaut berbasis online kepada pengguna jasa, petugas pelayanan tidak melaksanakan hal tersebut tetapi semuanya dilakukan secara otodidak seperti sosialisasi langsung kepada pengguna jasa yang datang di Kantor Kesyahbandaran Utama Makassar dengan cara menjelaskan kepada pengguna jasa tata cara melakukan registrasi online penerbitan buku pelaut,. Kalau dalam bentuk sosialisasi ke tempat-tempat tertentu, Petugas pelayanan tidak melakukan hal tersebut karena tidak ada instruksi dari Pusat dalam hal ini Direktorat Jenderal Perhubungan Laut.

Berdasarkan keterangan dari Yuyun Sri Wahyuni mengenai permasalahan sosialisasi SOP, pihak Syahbandar tidak melakukan hal tersebut sebab tidak ada instruksi dari Direktorat Jenderal Perhubungan Laut. Sehingga mengenai sosialisasi SOP penerbitan buku pelaut berbasis online dilakukan dengan cara otodidak seperti penjelasan secara langsung kepada pengguna jasa yang datang ke Kantor Kesyahbandaran Utama Makassar dan melalui pemasangan banner-banner mengenai alur prosedur penerbitan buku pelaut berbasis online. Oleh sebab itu, tidak jarang ditemukan kesulitan memperoleh informasi mengenai prosedur pelayanan penerbitan buku pelaut online jika tidak mendatangi Syahbandar. Namun sejatinya, pelayanan penerbitan buku pelaut telah berbasis online sehingga sosialisasi prosedur semestinya dapat dilakukan dengan 
Harianty Anwar, dkk, Pelayanan Penerbitan Buku Pelaut Berbasis Online |15

mengakses situs tertentu namun semuanya harus dilakukan dengan mendatangi Kantor Kesyahbandaran Utama Makassar untuk mengetahui detail alur prosedur pelayanna penerbitan buku pelaut berbasis online.

Senada dengan keterangan yang tidak jauh berbeda dengan Yuyun Sri Wahyuni, ST. adapun pemaparan Staff Seksi Kepelautan Kantor Kesyahbandaran Makassar Hesthi Triyono, SS (wawancara, 20 Maret 2017) yaitu :

Petugas pelayanan telah mensosialisasikan hal tersebut melalui banner-banner yang tertera di depan ruang pelayanan satu atap dan dulu diadakan sosialisasi ke PIP dan AMI Veteran dan mengundang pengguna jasa seperti mahasiswa Taruna ke Syahbandar namun tidak semua pengguna jasa yang datang ke Syahbandar minimal 2 orang perwakilan setiap kelas dari pengguna jasa mengingat waktu dan tempat yang terbatas. Untuk petugas pelayanan yang mengadakan sosialisasi diluar Kantor Kesyahbandaran Utama Makassar tidak pernah dilaksanakan karena pengguna jasa seperti pelaut sangat susah untuk dihubungi namun ada perwakilan pengguna jasa seperti pelaut memilki komunitas KPI (Kesatuan Pelaut Indonesia) datang ke Syahbandar jadi petugas pelayanan menjelaskan kepada pengguna jasa tata cara melakukan pendaftaran online

Menurut Hesthi Triyono, SS, petugas telah melakukan sosialisasi dengan menggunakan banner-banner yang tertera di Kantor Kesyahbandaran Utama Makassar dan dengan mendatangkan beberapa pengguna jasa dari beberapa kampus pelayaran dan selanjutnya diharapkan mewakili mahasiswa-mahasiswa pelayaran untuk ikut mensosialisasikan alur prosedur pelayanan penerbitan buku pelaut berbasis online. Namun menurut Hesthi Triyono, SS juga, sosialisasi yang paling sering petugas pelayanan lakukan ialah memberikan sosialisasi kepada pengguna jasa yang datang ke Syahbandar. Selanjutnya peneliti menemukan kesamaan pemaparan mengenai sosialisasi dalam bentuk banner-banner namun keberadaannya luput dari pengguna jasa. Ukuran banner yang kecil dan letak yang tidak strategis mengakibatkan ketidaktahuan pengguna jasa dalam sosialisasi dalam bentuk banner.

Mengenai tata cara pelayanan yang telah ditentukan apakah berjalan sesuai dengan SOP dan membandingkan antara pelayanan penerbitan buku pelaut berbasis online dan pelayanan penerbitan buku pelaut berbasis manual selanjutnya dikemukakan oleh pengguna jasa berdasarkan keterangan dari Muhammad Arfandi (wawancara, 22 Maret 2017):

Pengguna jasa merasa sudah sesuai dengan standar operasional prosedur yang ditetapkan dan pengguna jasa tidak mengalami kesulitan jika dibandingkan dengan sistem manual yang harus mencari ke beberapa tempat mengenai informasi dan dengan diberlakukannya penerbitan buku pelaut berbasis online penggun jasa menjadi tahu alur pendaftaran dnegan mudah.. Cukup dengan melakukan pendaftaran secara online, buat situs gmail, melapor ke petugas pelayanan di Syahbandar, lalu proses akhir melakukan foto secara langsung di kantor Kesyahbandaran Utama Makassar.

Berdasarkan paparan dari Muhammad Arfandi sebagai pengguna jasa, Muhammad Arfandi merasa Syahbandar telah menjalankan pelayanan sesuai dengan prosedur yang berlaku dan Muhammad Arfandi merasakan kemudahan dalam pelayanan berbasis online daripda pelayanan sistem manual. Hal senada juga dikemukakan oleh pengguna jasa berdasarkan keterangan dari Hasriadi Abbas (wawancara, 22 Maret 2017): Petugas pelayanan telah melaksanakan prosedur dengan baik sesuai dengan standar yang diberlakukan dan mengenai penerbitan buku pelaut berbasis manual dan berbasis online. Sedangkan menurut Dian dalam paparan yang dikemukakan 
memiliki sedikit paparan yang berbeda dengan beberapa pengguna jasa lainnya, yaitu: (wawancara, 22 Maret 2017): Prosedur yang ditetapkan sudah berjalan dengan baik dan pengguna jasa dalam pelayanan penerbitan buku pelaut berbasis online ini tidak mengeluarkan biaya.

Prosedur yang ditetapkan oleh pihak Syahbandar rupanya banyak dirasakan kemudahan dan sudah berjalan dengan baik menurut pengguna jasa yang telah melaksanakan pelayanan penerbitan buku pelaut berbasis online. Mengenai paparan yang dikemukakan oleh Dian dalam hal biaya yang tidak dikeluarkan dalam pelayanan tersebut dikarenakan Dian adalah pengguna jasa taruni yang semua biaya pendidikan dan kelengkapan dokumen administratif dan teknis untuk bergabung di kapal ditanggung oleh Kementerian Perhubungan melalui kebijakan Presiden Joko Widodo mengenai beasiswa kemaritiman bagi 6.000 taruna-taruni tidak mampu. Sehingga Dian dan beberapa pengguna jasa yang diwawancarai oleh peneliti tidak mengeluarkan biaya memperoleh pelayanan.

Selanjutnya pengguna jasa bernama Muh. Abduh memberikan keterangan mengenai prosedur pelayanan yaitu (wawancara, 22 Maret 2017): Iya, prosedur yang dilaksanakan sudah sesuai. Namun masih ditemukan keterangan berbeda dari pengguna jasa bernama Bolkia mengenai prosedur pelayanan yaitu (wawancara, 22 Maret 2017):

Sudah sesuai dengan SOP namun ketika pengguna jasa melakukan pendaftaran secara online penggun jasa menghabiskan waktu untuk menunggu sekitar 3 minggu. Hal tersebut tidak sesuai dengan SOP dan alasan yang dipaparkan oleh petugas pelayanan ialah adanya gangguan jaringan dari server di pusat dan hal tersebut mengakibatkan pengguna jasa kehilangan kesempatan untuk bergabung di kapal diakibatkan keterlambatan penerbitan buku pelaut berbasis online.

Menurut Bolkia, sejatinya pelayanan sudah sesuai dengan SOP namun Bolkia menemukan hambatan dalam hal pendaftaran secara online dan menghabiskan waktu selama 3 minggu hanya untuk menunggu penerbitan kode billing untuk melanjutkan proses pendaftaran online. Karena hambatan yang dialami oleh Bolkia, Bolkia mengalami kerugian material dan nonmaterial sebab kesempatan untuk bergabung dengan kapal menjadi tertunda. Berdasarkan kasus tersebut, peneliti menanyakan kepada pejabat terkait dan mengatakan keterlambatan tersebut diakibatkan oleh server dari pusat yang begitu padat dan banyak diakses oleh pengguna jasa seluruh Indonesia sehingga keterlambatan penerbitan kode billing terjadi. Semestinya Bolkia datang dan melaporkan kejadian tersebut sehingga memperoleh solusi atas permasalahan tersebut.

Dari 5 pengguna jasa yang diwawancara oleh peneliti, 4 diantaranya mengatakan prosedur yang ditetapkan oleh pihak Syahbandar telah sesuai prosedur dan mendapatkan kemudahan antara penerapan pelayanan berbasis online dan penerapan pelayanan berbasis manual. sehingga dapat disimpulkan bahwa sistem online dirasa memudahkan pengguna jasa. Oleh sebab itu, dapat ditarik kesimpulan bahwa dari beberapa keterangan yang disampaikan oleh informan bahwa prosedur Pelayanan Penerbitan Buku Pelaut Berbasis Online pada Kantor Kesyahbandaran Utama Makassar sudah sesuai dan cukup efektif.

\section{Waktu Penyelesaian}

Waktu pelayanan adalah jangka waktu yang diperlukan untuk menyelesaikan seluruh proses pelayanan dari setiap jenis pelayanan. Kemudian harus ditetapkan standar waktu penyelesaian pelayanan yang ditetapkan sejak saat pengajuan permohonan sampai dengan 
Harianty Anwar, dkk, Pelayanan Penerbitan Buku Pelaut Berbasis Online |17

penyelesaian pelayanan termasuk pengaduan. Berdasarkan keterangan Saharuddin, ST Kepala Seksi Kepelautan Kantor Kesyahbandaran Utama Makassar mengenai waktu dan permasalahan yang dialami oleh beberapa pengguna jasa dalam pelayanan penerbitan buku pelaut berbasis online (wawancara, 22 Maret 2017) menjelaskan bahwa:

Berbicara mengenai waktu, petugas jasa pernah menerbitkan buku pelaut berbasis online selama 1 hari, ketika pada saat awal diberlakukannya penerbitan buku pelaut berbasis online namun saat ini petugas pelayanan memakan waktu kurang lebih selama 7 hari dalam penerbitan buku pelaut berbasis online. Terkadang pengguna jasa telah melakukan pendaftaran secara online dan beberapa hari setelah melakukan proses pendaftaran online pengguna jasa memperoleh kode billing. Namun karena kesibukan serta penundaan waktu untuk melakukan pembayaran pada bank yang telah ditunjuk, hal tersebut mengakibatkan penundaan penerbitan buku pelaut mengingat waktu pembayaran setelah menerima kode billing ialah 3 hari. Jadi, ketika pengguna jasa telah menerima kode billing dan telah melewati batas waktu pembayaran, pengguna jasa harus mendaftar bulang secara online lagi.

Menurut Saharuddi, ST, waktu pelayanan yang disediakan dalam menyelesaikan penerbitan buku pelaut minimal 3 hari. Cepat atau lambatnya penyelesaian penerbitan buku pelaut berbasis online tergantung oleh beberapa faktor, yakni server dari pusat yang memungkinkan kecepatan penyelesaian pelayanan dan keaktifan pengguna jasa dalam menyelesaiakn proses penerbitan buku pelaut berbasis online. Apabila salah satu dari kedua faktor tersebut tidak terlaksana dengan baik, tentunya akan menghambat waktu penyelesaian pelayanan penerbitan buku pelaut berbasis online.

Senada dengan paparan Saharuddin, ST, Staff Seksi Kepelautan Kantor Kesyahbandaran Makassar Yuyun Sri Wahyuni, ST memberikan paparan yang sama mengenai waktu pelayanan penerbitan buku pelaut berbasis online (wawancara, 20 Maret 2017):

Berhubung Kantor Kesyahbandaran Utama Makassar telah melaksanakan sistem online dan baru dilaksanakan sehingga jaringan yang bermasalah atau ada kendalan lain jadi petugas pelayanan membutuhkan waktu selama 3 hari. Hal tersebut sesuai dengan SOP.

Syahbandar sebagai tim eksekutor kebijakan mengenai pelaksanaan pelayanan sistem online tentunya telah melaksanakan dengan sebaik mungkin dan juga memperhatikan waktu penyelesaian pelayanan yakni minimal selama 3 hari. Hal senada juga diungkapkan oleh Staff Seksi Kepelautan Kantor Kesyahbandaran Makassar Hesthi Triyono, SS mengenai waktu pelayanan penerbitan buku pelaut berbasis online (wawancara, 20 Maret 2017):

Petugas pelayanan membutuhkan waktu selama 3 hari dan sesuai dengan SOP. Bahkan pengguna jasa terkadang membutuhkan waktu hanya 2 hari karena pengguna jasa yang melakukan pendaftaran online hanya sedikit dan tidak ada gangguan pada jaringan sehingga sumber permasalahan sistem itu dari pusat.

Dari hasil wawancara dengan Kepala Seksi Kepelautan dan Staff Seksi Kepelautan dapat disimpulkan bahwa waktu pelayanan penerbitan buku pelaut berbasis online kurang lebih selama 3 hari. Hal tersebut memungkinkan terjadinya kecepatan dan keterlambatan penyelesaian waktu pelayanan sangat bergantung pada beberapa aspek pendukung. Sedikitnya pengguna jasa yang melakukan pendaftaran online dan berjalannya server dengan baik serta keaktifan pengguna jasa 
dalam menyelesaikan proses pendaftaran buku pelaut memungkinkan terjadinya kecepatan penerbitan buku pelaut berbasis online.

Adapun keterangan yang disampaikan oleh pengguna jasa Muhammad Arfandi mengenai ketepatan waktu pelayanan yang diberikan oleh petugas pelayanan di Kantor Kesyahbandaran Utama Makassar yaitu (wawancara, 22 Maret 2017):

Terkadang sesuai terkadang juga tidak sesuai tetapi sejauh ini waktu yang diberikan hampir sesuai dengan prosedur. Namun akhir-akhir ini ada gangguan pada jaringan. Alasan yang dikemukakan oleh petugas pelayanan mohon maaf jaringan sedang bermasalah mohon bersabar karena banyaknya jumlah pendaftar online oleh pengguna jasa sehingga mengakibatkan permasalahan pada jaringan.

Hal serupa dipaparkan oleh pengguna jasa Hasriadi Abbas mengenai ketepatan waktu pelayanan yang diberikan oleh petugas pelayanan di Kantor Kesyahbandaran Utama Makassar yaitu (wawancara, 22 Maret 2017): Sudah sesuai dengan prosedur yang telah ditentukan. Dari paparan kedua pengguna jasa yakni Muhammad Arfandi dan Hasriadi Abbas mengemukakan sejauh ini pelayanan terkadang sudah sesuai kadang tidak sesuai namun belakangan ini terjadi gangguan pada jaringan sehingga mengalami keterlambatan. Namun lain halnya keterangan dari pengguna jasa bernama Dian mengenai waktu yang telah ditentukan (wawancara, 22 Maret 2017):

Pengguna jasa belum mengetahui berapa lama waktu yang diberikan dalam penerbitan buku pelaut berbasis online ini karena pengguna jasa hanya diminta untuk ke Kantor Syahbandar untuk mengambil foto.

Pengguna jasa bernama Dian belum mengetahui berapa lama waktu yang ditentukan oleh pihak Syahbandar dalam penerbitan buku pelaut berbasis online sebab Dian tidak melewati tahap penyelesaian hingga akhir penerbitan buku pelaut berbasis online. Dian hanya menyerahkan beberapa dokumen pendukung penerbitan buku pelaut dan untuk tahap selanjutnya. Dari hasil pengamatan yang dilakukan oleh peneliti ketika mengadakan wawancara dengan Dian, peneliti melihat untuk Taruna dan Taruni yang masuk di program beasiswa Kemaritiman ada seorang staff di instansi terkait yang menangani beasiswa Kemaritiman bagi Taruna dan Taruni yang turut serta membantu tahap pendaftaran hingga penerbitan buku pelaut bagi Taruna dan Taruni. Sehingga Dian dan beberapa Taruna dan Taruni yang mengikuti program beasiswa Kemaritiman hanya diminta datang ke Syahbandar untuk melakukan foto buku pelaut.

Selanjutnya keterangan lain dipaparkan oleh Muh. Abduh yaitu (wawancara, 22 Maret 2017): Sepertinya ada keterlambatan karena permasalahan pada jaringan dan petugas pelayanan mengatakan permasalahan tersebut dari pusat.

Rupanya ditemukan keterlambatan penerbitan buku pelaut yang dialami oleh Muh. Abduh dan keterlabatan tersebut berasal dari jaringan oleh Server pusat. Namun, menurut keterangan dari Bolkiah mengenai waktu yang disediakan mengenai Pelayanan Penerbitan Buku Pelaut Berbasis Oline pada Kantor Kesyahbandaran Utama Makassar menyampaikan hal yang berbeda dari pengguna jasa lainnya (wawancara, 22 Maret 2017):

Tidak sesuai dengan SOP karena pengguna jasa sudah menunggu selama 3 minggu dimulai dari tanggal 1 Maret pengguna jasa melakukan pengambilan foto, dokumen telah dimasukkan dan petugas pelayanan mengatakan harap menunggu kode billing, tetapi kenyataannya pengguna jasa menerima baru menerima kode biling sekitar 2 minggu setelah melakukan proses registrasi akhir. Ketika telah diterima kode billing, waktu yang diberikan kepada pengguna jasa untuk membayar selama 2 hari. Apabila selama 2 hari pengguna jasa belum membayar di bank yang telah ditunjuk, 
Harianty Anwar, dkk, Pelayanan Penerbitan Buku Pelaut Berbasis Online |19

seperti bank BRI, BNI, Mandiri, dan Kantor Pos, pengguna jasa akan melakukan pendaftaran ulang kembali dari awal.

Ketidak sesuaian dengan SOP mengenai pelayanan penerbitan buku pelaut rupanya dirasakan oleh Bolkia dan merasa waktu pembayaran kode billing di bank-bank yang ditunjuk oleh Syahbandar waktunya hanya sedikit. Sehingga ketika waktu penentuan pembayaran kode billing telah terlewati dan Bolkia tidak membayar sesuai dengan waktu yang ditentukan, maka Bolkia akan mengulang proses pendaftaran buku pelaut berbasis online. Tentunya hal tersebut dirasa sangat merugikan bagi pengguna jasa karena apabila telah melakukan pembayaran berdasarkan nominal dari kode billing tersebut, proses penyelesaian buku pelaut akan lebih sedikit.

Dari hasil wawancara dengan informan, ternyata waktu pelayanan penerbitan buku pelaut berbasis online menemui pro dan kontra. Sebab beberapa informan yaitu Kepala Seksi Kepelautan dan Staff Seksi Kepelautan mengatakan waktu penyelesaian buku pelaut berbasis online selama 3 hari dan bahkan hanya memakan waktu selama 1 sampai 2 hari tetapi waktu penyelasaian bbuku pelaut berbasis online ditentukan oleh beberapa faktor seperti server yang baik dari pusat serta keaktifan pengguna jasa dalam menyelesaikan proses pendaftaran buku pelaut berbasis online. Namun lain halnya dengan beberapa pengguna jasa yang hampir semua mengatakan bahwa waktu yang ditentukan oleh pihak Syahbandar tidak sesuai dengan waktu yang diperoleh dalam pelayanan buku pelaut berbasis online sehingga tentunya menuai pro dan kontra.

Sedangkan berdasarkan hasil observasi langsung pada loket 1 pelayanan satu atap di Kantor Kesyahbandaran Utama Makassar (27 Maret 2017) ternyata waktu yang ditentukan oleh pihak petugas pelayanan tidak sesuai dengan waktu yang didapatkan oleh pengguna jasa. Hal tersebut dikarenakan permasalahan jaringan dari pusat yang menyebabkan keterlambatan penerbitan buku pelaut berbasis online dan banyaknya pendaftar online dari berbagai wilayah dan diteruskan ke Direktorat Jenderal Perhubungan Laut sebagai server serta penyetujuan dokumen pendaftaran online pada pengguna jasa yang mengakibatkan masalah tersebut.

Kantor Kesyahbandaran Utama Makassar sebagai penyedia jasa penerbitan buku pelaut berbasis online dan dikatakan sebagai operator dari sebuah kebijakan sistem baru yang memberlakukan peralihan dari penerbitan buku pelaut berbasis manual ke penerbitan buku pelaut berbasis online tidak bisa berbuat banyak. Jika petugas pelayanan melakukan sebuah tindakan berupa pemecahan masalah tentu akan menyalahi aturan SOP tetapi dari hasil observasi yang dilakukan secara langsung, peneliti melihat petugas pelayanan tidak menggunakan alat yang diberikan oleh Direktoran Jenderal Perhubungan Laut. Sebagai pengeksekusi kebijakan, petugas pelayanan menemukan solusi dari permasalahan yang banyak dikeluhkan pengguna jasa dengan menggunakan koneksi internet yang baik yang merupakan fasilitas pribadi dari Kantor Kesyahbandaran Utama Makassar agar mencapai pelayanan yang optimal.

\section{Biaya Pelayanan}

Biaya adalah ongkos yang dikenakan kepada penerima layanan dalam mengurus dan/atau memperoleh pelayanandari penyelenggara yang besarnya ditetapkan berdasarkan kesepakatan 
antara penyelenggara dan masyarakat. Proses identifikasi biaya pelayanan juga dilakukan berdasarkan setiap tahapan dalam prosedur pelayanan. Berapa biaya yang diperlukan untuk masing-masing tahapan pelayanan. Pada proses ini juga sekaligus diidentifikasi biaya yang akan dibebankan pelanggan dan biaya yang akan dibebankan unit pengelola pelayanan. Penghitungan dua komponen biaya pelayanan ini penting dilakukan, untuk mengetahui berapa jumlah biaya yang akan dibebankan ke pelanggan, dan berapa biaya yang dibebankan kepada pengelola dan juga harus ditetapkan standar biaya/tarif pelayanan termasuk rinciannya yang ditetapkan dalam proses pemberian pelayanan. Hendaknya setiap kenaikan tarif/biaya pelayanan diikuti dengan peningkatan kualitas pelayanan

Berdasarkan keterangan Saharuddin, ST Kepala Seksi Kepelautan Kantor Kesyahbandaran Utama Makassar mengenai peraturan yang mengatur mengenai masalah biaya yang dikeluarkan oleh pengguna jasa (wawancara, 22 Maret 2017) menjelaskan bahwa:

Saat ini berdasarkan PP Penerima Negara Bukan Pajak nomor 15 Tahun 2016 untuk penerbitan buku pelaut biayanya Rp.100.000 dan biaya tersebut dibayar pada bank yang telah ditunjuk dengan memperlihatkan kode billing setelah melakukan pendaftaran online. Dahulu biaya penerbitan buku pelaut berbasis manual hanya Rp. 10.000 tetapi melihat kondisi saat ini yang telah melakukan penerbitan buku pelaut berbasis online, sudah tidak memungkinkan diberlakukan tarif dahulu. Pengguna jasa regular seperti taruna, pelaut dan pengguna jasa yang dibiayai oleh pemerintah biaya yang dikenakan tetap sama.

Menurut Saharuddin, ST, biaya yang harus dikeluarkan oleh pengguna jasa baik pengguna jasa reguler maupun pengguna jasa yang masuk dalam program beasiswa kemaritiman sebesar Rp 100.000 dan biaya tersebut telah diatur pada PNBP (Penerima Negara Bukan Pajak) PP No. 15 Tahun 2016. Hal tersebut sejalan dengan keterangan Staff Seksi Kepelautan Kantor Kesyahbandaran Makassar Yuyun Sri Wahyuni, ST dan Hesthi Triyono, SS mengenai biaya yang dikeluarkan oleh pengguna jasa mengenai pelayanan penerbitan buku pelaut berbasis online (wawancara, 20 Maret 2017): Biayanya Rp. 100.000 sesuai dengan PP No. 15 Tahun 2016. Senada dengan keterangan Kepala Seksi Kepelautan dan Staff Seksi Kepelautan, Muhammad Arfandi, Muh. Abduh, dan Bolkia menyampaikan wacana tersebut: (wawancara, 22 Maret 2017): Biayanya sebesar Rp 100.000.

Ternyata biaya yang dikeluarkan oleh pengguna jasa untuk menerbitkan buku pelaut sesuai dengan PNBP PP No. 15 Tahun 2016. Sehingga dapat dikatakan bahwa pembayaran tersebut bebas dari pungli karena pengguna jasa tidak mengeluarkan biaya yang lebih dari penerapan pihak Syahbandar. Namun keterangan berbeda dikemukakan oleh Hasriadi Abbas mengenai biaya yang dikeluarkan oleh pengguna jasa mengenai pelayanan penerbitan buku pelaut berbasis online (wawancara, 20 Maret 2017):

Sejauh ini, pengguna jasa kurang tahu berapa besaran biaya sebab pengguna jasa mendapatkan anggaran dari APBN pemerintah mengenai program untuk penerbitan buku pelaut berbasis online.

Adapun keterangan berbeda dikemukakan oleh Dian mengenai biaya yang dikeluarkan oleh pengguna jasa mengenai pelayanan penerbitan buku pelaut berbasis online (wawancara, 20 Maret 2017): Tidak ada biaya yang pengguna jasa keluarkan karena ini adalah bantuan dari pemerintah jadi biayanya gratis. Keterangan Hasriadi Abbas dan Dian mengenai biaya pelayanan penerbitan buku pelaut berbasis online yang mengatakan ketidaktahuan besaran biaya dan biaya 
Harianty Anwar, dkk, Pelayanan Penerbitan Buku Pelaut Berbasis Online |21

yang gratis sebab Hasriadi Abbas dan Dian merupakan pengguna jasa yang menerima bantuan beasiswa kemaritiman sehingga Hasriadi Abbas dan Dian digratiskan.

Dari uraian tersebut terdapat kesamaan biaya yang dipaparkan oleh petugas pelayanan dan pengguna jasa sehingga dapat disimpulkan bahwa adanya kewajaran biaya dan peraturan yang berlaku yang menyebutkan bahwa biaya yang dikeluarkan oleh pengguna jasa sebesar $\mathrm{Rp}$ 100.000. Meskipun ditemukan keterangan lain dari pengguna jasa yang tidak mengetahui besaran biaya serta mengatakan penerbitan buku pelaut berbasis online tidak dipungut biaya namun keterangan dari Bapak Saharuddin selaku Kepala Seksi Kepelautan Kantor Kesyahbandaran Utama Makassar, pengguna jasa tersebut merupaka pengguna jasa yang dibiaya oleh pemerintah dari pelatihan-pelatihan dasar kepelautan hingga kelengkapan dokumen-dokumen kapal seperti buku pelaut dan pengguna jasa tersebut tetap mengeluarkan biaya penerbitan buku pelaut berbasis online. Biaya yang dikeluarkan tetap sama nominalnya degan pengguna jasa regular tetapi yang membiayai penerbitan buku pelaut berbasis online tersebut oleh Kementerian Perhubungan.

\section{Produk Pelayanan}

Produk pelayanan adalah hasil pelayanan yang diberikan dan diterima sesuai dengan ketentuan yang telah ditetapkan. Produk pelayanan dapat berupa penyediaan barang, jasa dan/atau produk administrasi yang diberikan dan diterima pengguna layanan sesuai dengan ketentuan perundang-undangan yang ditetapkan. Proses identifikasi produk pelayanan dapat dilakukan berdasarkan keluaran (output) yang dihasilkan dari setiap tahap pelayanan. Hasil akhir dari prosedur pelayanan inilah yang menjadi "produk" dari suatu jenis pelayanan. Selain itu, harus ditetapkan standar produk (hasil) pelayanan yang akan diterima sesuai dengan ketentuan yang telah ditetapkan. Dengan harga pelayanan yang telah dibayarkan oleh masyarakat, mereka akan mendapatkan pelayanan berupa apa saja.

Berdasarkan keterangan Saharuddin, ST Kepala Seksi Kepelautan Kantor Kesyahbandaran Utama Makassar produk pelayanan yang sediakan sudah sesuai dengan peraturan yang berlaku (wawancara, 22 Maret 2017) menjelaskan bahwa:

Memang harus seperti itu, karena petugas pelayanan sebagai pengeksekusi kebijakan dan sebagai takaran implementasi kebijakan yang dibuat oleh pusat untuk dilaksanakan di UPT-UPT itu sudah pasti sesuai dengan produk yang telah ditentukan dan tidak mungkin bergeser dari kebijakan. Apalagi dengan adanya sistem, misalnya ada yang tidak sesuai dengan sistem, petugas pelayanan tidak akan menindaklanjuti data pengguna jasa tersebut dan tentu petugas pelayanan memeriksa berbagai kelengkapan dokumen apakah data tersebut telah lengkap atau tidak.

Kantor Kesyahbandaran sebagai pengeksekusi kebijakan yang berlaku tentunya harus menjalankan sesuai dengan prosedur dan produk dari pelayanan tersebut ialah buku pelaut dimana buku pelaut sangatlah penting kegunaannya bagi pengguna jasa yang akan melaksanakan praktek ataupun bekerja di kapal.

Sementara hal tersebut sejalan dengan keterangan Staff Seksi Kepelautan Kantor Kesyahbandaran Makassar Yuyun Sri Wahyuni, ST dan Hesthi Triyono, SS mengenai produk pelayanan yang sediakan sudah sesuai dengan peraturan yang berlaku (wawancara, 20 Maret 2017): Kalau mengenai SOP, petugas pelayanan selalu sesuai dalam melakukan prosedur. Tentunya antara Kepala Seksi Kepelautan dan Staff Seksi Kepelautan melakukan hal yang sama 
yaitu kesamaan menjalankan prosedur yang sudah sesuai dengan SOP. Selanjutnya mengenai pelayanan yang diberikan oleh petugas pelayanan terhadap pemenuhan hasil yang optimal dalam hal memberikan pelayanan dikemukakan oleh pengguna jasa berdasarkan keterangan dari Muhammad Arfandi, Dian, Muh. Abduh, dan Bolkia (wawancara, 22 Maret 2017) yaitu:

Kalau pengguna jasa secara pribadi mengatakan sudah berjalan optimal dan lebih baik dari sebelumnya terutama adanya sistem online saat ini jika dibandingkan dengan dahulu saat masih menggunakan sistem manual pengguna jasa kesulitan memperoleh informasi dan harus mencari informasi kesana kemari.

Menurut Muhammad Arfandi, Dian, Muh. Abduh dan Bolkia mengemukakan pelayanan sudah sesuai dan berjalan optimal. Terutama dengan adanya sistem online dalam pelayanan penerbitan buku pelaut dirasakan oleh beberapa pengguna jasa jauh lebih baik dari sistem manual yang memakan waktu pelayanan yang jauh lebih lama. Namun, lain halnya dengan pengguna jasa Hasriadi Abbas yang memaparkan hal yang berbeda (wawancara, 22 Maret 2017) yaitu: Sampai saat ini pengguna jasa kurang tahu mengenai hal tersebut. Mengenai paparan Hasriadi Abbas yang kurang mengetahui hal tersebut sebab Hasriadi Abbas baru sekali mengunjungi Kantor Kesyahbandaran Utama Makassar sehingga Hasriadi Abbas masih kurang paham mengenai produk pelayanan yang diberikan petugas pelayanan.

Dari uraian tersebut dapat diketahui bahwa produk pelayanan yang disediakan oleh petugas pelayanan sudah sesuai dengan peraturan yang berlaku mengenai hasil dari produk pelayanan. Berdasarkan observasi langsung yang dilakukan peneliti bahwa hasil dari produk pelayanan ini adalah buku pelaut dan tertera jelas di halaman lampiran bahwa persyaratan untuk bergabung dengan kapal dan sebagai kelengkapan dokumen mewajibkan kepada seluruh pengguna jasa dalam hal ini pelaut untuk memiliki buku pelaut sebagai salah satu identitas. Mengenai ketidaktahuan salah satu pengguna jasa dikarenakan pengguna jasa tersebut minim informasi. Hal tersebut dikarenakan pengguna jasa baru menempuh pendidikan dasar dan baru sekali mengunjungi Kantor Kesyahbandaran Utama Makassar sehingga belum begitu jauh mengetahui produk pelayanan tersebut.

\section{Sarana dan Prasarana}

Sarana dan prasarana merupakan salah satu dari standar pelayanan publik. Penyediaan sarana dan prasarana pelayanan yang memadai oleh penyelenggara pelayanan publik sangat menentukan dan menunjang keberhasilan penyelenggaraan pelayanan dan juga harus ditetapkan standar sarana dan prasarana pelayanan yang memadai oleh penyelenggara pelayanan publik.

Dari hasil observasi yang dilakukan oleh peneliti di Kantor Kesyahbandaran Utama Makassar pada tanggal 25 Maret 2017, peneliti menemukan sarana dan prasarana yang optimal dan cukup memadai dalam pelayanan penerbitan buku pelaut. Hal tersebut dibenarkan dengan ketersediaan ruang tunggu berupa kursi bagi pengguna jasa. Tetapi tidak sedikit pengguna jasa yang mengeluhkan ketersediaan ruang tunggu yang tidak nyaman karena hanya disediakan kursi. Pengguna jasa menginginkan adanya penyejuk ruangan seperti kipas angin dan juga media hiburan seperti televisi dan dapat dilihat pada lampiran gambar 12.

Minimnya ketersediaan kotak kritik dan saran dan tidak tersedianya sarana dan wadah khusus pengaduan seperti portal sms pengaduan dan web pengaduan mengenai pelayanan yang dapat menjadi tolak ukur semakin otimalnya pelayanan kedepannya dirasa pengguna jasa kurang optimal dan kurang efektif. Hal tersebut diperkuat dengan hasil observasi yang peneliti lakukan pada tanggal 25 Maret 2017. Ketersediaan kotak kritik dan saran hanya tersedia satu 
kotak kritik dan saran. Letak yang luput dari jangkauan pengguna jasa untuk mengakses kotak kritik dan saran tersebut mengakibatkan kurangnya pembaharuan isi dari kotak kritik dan saran tersebut sehingga pengguna jasa hanya melaporkan beberapa keluhan yang dianggap kurang menyenangkan pada loket-loket yang tersedia pada pelayanan terpadu satu atap Kantor Kesyahbandaran Utama Makassar.

\section{Kompetensi Petugas Pemberi Pelayanan}

Kompetensi petugas pemberi pelayanan merupakan salah satu dari standar pelayanan publik. Kompetensi petugas pemberi pelayanan harus ditetapkan dengan tepat berdasarkan pengetahuan, keahlian, keterampilan, sikap dan perilaku yang dibutuhkan agar pelayanan yang diberikan bermutu. Hal tersebut perlu ditetapkan sebagai standar kompetensi petugas pemberi pelayanan berdasarkan pengetahuan, keahlian, keterampilan, sikap, dan perilaku yang dibutuhkan.

Berdasarkan hasil observasi yang dilakukan peneliti pada tanggal 25 Maret 2017 di Kantor Kesyahbandaran Utama Makassar, mengenai penerbitan buku pelaut yang dilakukan pada seksi kepelautan peneliti melihat petugas pemberikan pelayanan sudah sesuai dengan kompetensi yang mereka miliki. Hal tersebut didasarkan pada beberapa staff yang memiliki latar belakang pendidikan di bidang teknis dan kepala Kantor Kesyahbandaran Utama Makassar menegaskan bahwa petugas pemberi pelayanan terkhusus pada bagian pelaksana teknis seperti seksi kepelautan, tentu harus memiliki kemampuan, pengetahuan, sikap dan perilaku yang sesuai dengan kompetensi yang ada. Jadi dapat disimpulkan bahwa petugas pemberi pelayanan kepada pengguna jasa memang harus sesuai dengan kompetensi yang dimiliki dalam hal kepelautan agar pelayanan yang diberikan tidak mengalami hambatan internal hanya karena kemampuan dan keahlian yang dimiliki oleh petugas pemberi pelayanan.

\section{SIMPULAN}

Berdasarkan hasil penelitian mengenai Pelayanan Penerbitan Buku Pelaut Berbasis Online pada Kantor Kesyahbandaran Utama Makassar dapat ditarik kesimpulan adalah Pelayanan Penerbitan Buku Pelaut Berbasis Online pada Kantor Kesyahbandaran Utama Makassar secara keseluruhan sudah berjalan dengan efektif. Dengan melihat aspek yaitu: (1) identifikasi Persyaratan, (2) Indentifikasi Prosedur, (3) Identifikasi Waktu, (4) Identifikasi Biaya/Tarif, (5) Identifikasi Produk Pelayanan, (6) Penanganan Pengadaan Pengaduan. Adapun kekurangan dari pelayanan penerbitan buku pelaut berbasis online terdapat di beberapa indikator yang perlu ditingkatkan seperti identifikasi waktu dan penanganan pengadaan pengaduan.

\section{DAFTAR PUSTAKA}

Al Fatta, H. (2007). Analisis dan Perancangan Sistem Informasi untuk keunggulan bersaing perusahaan dan organisasi modern. Penerbit Andi.

Effendi, M. A., \& Purnama, B. E. (2011). Perancangan Sistem Layanan Informasi Akademik 
24| Jurnal Ilmiah Ilmu Administrasi Publik, Vol.7, No.1, 2017

Berbasis Short Message Service. Speed-Sentra Penelitian Engineering Dan Edukasi, 3(2). Gaol, C. J. L. (2008). Sistem Informasi Manajemen. Grasindo.

Lembaga Administrasi Negara. (2003). Penyusunan Standar Pelayanan Publik. Lembaga tsb.

Miles, M. B., Huberman, A. M., \& Saldana, J. (2014). Qualitative Data Analysis: A Methods Sourcebook (3rd ed.). United States of America: Sage Publications.

Nasikin, K. (2011). Pengembangan Sistem Informasi Akademis Dan Keuangan Di MAN 2 Pati. Speed-Sentra Penelitian Engineering Dan Edukasi, 3(3).

Novistia, N. F. (2016). Sistem Pemeriksaan Kapal Berbasis Desktop Pada Bidang Keselamatan Berlayar Kantor Kesyahbandaran Utama. Jurnal INSYPRO (Information System and Processing), 1(1).

Patria, L., \& Yulianto, K. (2011). Pemanfaatan Facebook untuk Menunjang Kegiatan Belajar Mengajar Online Secara Mandiri.

Putro, P. E., \& Riasti, B. K. (2012). Pembangunan Sistem Informasi Jaminan Kesehatan Rembang Sehat Berbasis Web Pada Dinas Kesehatan Kabupaten Rembang. Speed-Sentra Penelitian Engineering Dan Edukasi, 3(4).

Rofi'ah, A. (2013). Analisis SWOT dan Strategi Pemasaran Produk Simpanan Wadiah di BMT NU Sejahtera Semarang. IAIN Walisongo. 